\title{
Genetic diversity of cultivated accessions and wild species of rubber tree using EST-SSR markers
}

\author{
Juliana Morini Küpper Cardoso Perseguini(1), Lineu Roberto de Castro Romão(1), Boris Briñez ${ }^{(1)}$, \\ Erivaldo José Scaloppi Junior ${ }^{(2)}$, Paulo de Souza Gonçalves ${ }^{(3)}$ and Luciana Lasry Benchimol(3)
}

\begin{abstract}
(1)Universidade Estadual de Campinas, Campus Universitário Zeferino Vaz, s/no, Cidade Universitária, CEP 13083-970 Campinas, SP, Brazil. E-mail: julianamorini@hotmail.com, karlineu@yahoo.com.br, borisbrinez@hotmail.com ${ }^{(2)}$ Agência Paulista de Tecnologia dos Agronegócios, Rodovia Péricles Belini, Km 121, Caixa Postal 61, CEP 15500-970 Votuporanga, SP, Brazil. E-mail: scaloppi@apta.sp.gov.br (3)Instituto Agronômico de Campinas, Avenida Barão de Itapura, no 1.481, Jardim Guanabara, Caixa Postal 28, CEP 13012-970 Campinas, SP, Brazil. E-mail: paulog@iac.sp.gov.br, llasry@iac.sp.gov.br
\end{abstract}

\begin{abstract}
The objective of this work was to evaluate the efficiency of EST-SSR markers in the assessment of the genetic diversity of rubber tree genotypes (Hevea brasiliensis) and to verify the transferability of these markers for wild species of Hevea. Forty-five rubber tree accessions from the Instituto Agronômico (Campinas, SP, Brazil) and six wild species were used. Information provided by modified Roger's genetic distance were used to analyze EST-SSR data. UPGMA clustering divided the samples into two major groups with high genetic differentiation, while the software Structure distributed the 51 clones into eight groups. A parallel could be established between both clustering analyses. The 30 polymorphic EST-SSRs showed from two to ten alleles and were efficient in amplifying the six wild species. Functional EST-SSR microsatellites are efficient in evaluating the genetic diversity among rubber tree clones and can be used to translate the genetic differences among cultivars and to fingerprint closely related materials. The accessions from the Instituto Agronomico show high genetic diversity. The EST-SSR markers, developed from Hevea brasiliensis, show transferability and are able to amplify other species of Hevea.
\end{abstract}

Index terms: fingerprinting analysis, genetic structure, functional molecular markers, polymorphism information content, transferability.

\section{Diversidade genética de acessos cultivados e espécies silvestres de seringueira por meio de marcadores EST-SSR}

Resumo - O objetivo deste trabalho foi avaliar a eficiência de marcadores EST-SSR na determinação da diversidade genética de genótipos de seringueira e verificar a transferibilidade destes marcadores para espécies silvestres de Hevea. Foram utilizados 45 acessos de seringueira (H. brasiliensis) do Instituto Agronômico e seis espécies silvestres. As informações fornecidas pela distância genética de Roger modificada foram usadas para analisar os dados de EST-SSR. O agrupamento UPGMA dividiu as amostras em dois grandes grupos com alta diferenciação genética, enquanto o programa Structure distribuiu os 51 clones em oito grupos. Foi possível traçar um paralelo entre ambos os métodos de agrupamento. Os 30 EST-SSRs polimórficos mostraram de dois a dez alelos e foram eficientes em amplificar as seis espécies silvestres. Microssatélites funcionais EST-SSR são eficientes na avaliação da diversidade genética entre clones de seringueira e podem ser usados para traduzir diferenças genéticas entre cultivares e para gerar perfis genéticos de materiais próximos. Os acessos do Instituto Agronômico apresentam elevada diversidade genética. Os marcadores EST-SSR, desenvolvidos para Hevea brasilensis, apresentam transferabilidade e são capazes de amplificar outras espécies de Hevea.

Termos para indexação: análise de caracterização genética, estrutura genética, marcadores moleculares funcionais, conteúdo de informação polimórfica, transferabilidade.

\section{Introduction}

The rubber tree [Hevea brasiliensis (Willd. ex. Adr. de Juss.) Muell. Arg.] is native to the Amazonian rainforest and the most widely cultivated tree species for producing natural rubber tree latex, which has been an undeniably beneficial commodity for the past 100 years (Priyadarshan \& Gonçalves, 2003). Despite being the center of origin of the rubber tree and the main producer and exporter at the end of the $19^{\text {th }}$ century, Brazil started to import this raw material at the beginning of the last century. Data from the 
International Rubber Study Group (2011) showed that, in 2010, the world production of natural rubber reached 10,291 thousand tons, of which Brazil only contributed with 132 thousand tons, i.e., about $1 \%$ of the total.

Cultivated rubber tree clones are characterized by low genetic variability. According to Yu et al. (2011), the genetic basis of Hevea breeding programs has to be expanded in order to improve the breeding efficiency and to accelerate the breeding of new cultivars. However, the genetic base is decreasing and little improvement in the productivity of new cultivars is being achieved because of the long period of time required for interspecific breeding among related species.

The rubber tree is a perennial cross-pollinating and monoecious species of the Euphorbiaceae family, which has a long breeding process, with many selection cycles and difficulties in raising $F_{2}$ progenies. These difficulties are attributed to several factors related to the reproductive biology of rubber, such as lack of synchrony in flowering among clones, seasonality in flowering, pollen longevity, low pollination success, and seed recalcitrance (Gonçalves \& Marques, 2008). Therefore, conventional genetic analysis in this crop is difficult and time consuming (Saha et al., 2007).

Molecular markers have been used in several studies to assess genetic diversity among rubber tree genotypes (Roy et al., 2004; Saha et al., 2005). Microsatellites, or simple sequence repeats (SSRs), combine co-dominance, high polymorphism, good genome coverage, and Mendelian inheritance. Up to now, they have also been capable of discriminating closely related individuals (Brondani et al., 1998). Reports confirm the successful use and application of SSRs in rubber tree breeding (Feng et al., 2009; Le Guen et al., 2009, 2011; Gouvêa et al., 2010).

The presence of SSRs in the transcripts of genes indicates that they might have a role in gene expression or function; however, it remains to be seen whether any unusual phenotypic variation might be associated with the length of SSRs in coding regions (Varshney et al., 2005). This fact, together with the increasing availability of sequences in databases, mainly expressed sequence tags (ESTs), has enabled the development of functional microsatellite markers or EST-SSRs. The use of these markers has been reported in several species, including Hevea sp. (Feng et al., 2009). The fact that these markers are derived from genes and that, consequently, their sequences are more conserved, make it extremely robust to identify polymorphisms in closely related species (Varshney et al., 2005).

The objective of this work was to evaluate the efficiency of EST-SSR markers in assessing the genetic diversity of 51 rubber trees and to verify the transferability of these markers for six wild species of Hevea.

\section{Materials and Methods}

A total of 45 rubber tree genotypes ( $H$. brasiliensis) from the Instituto Agronômico (IAC, Campinas, SP, Brazil) and six wild species of Hevea (H. guianensis, $H$. rigidifolia, $H$. nitida, $H$. pauciflora, $H$. benthamiana, and $H$. camargoana), provided by Embrapa Amazônia Ocidental (Manaus, AM, Brazil), were used (Table 1). Total genomic DNA was extracted from powdered lyophilized young leaves using the CTAB method (Hoisington et al., 1994). The IAC genotypes were from Asiatic, African, Amazonian, and IAC series. Several of the Asiatic clones were derived from the Wickham collection originally introduced into Asia in 1876, which were known as the Wickham clones (Wycherley, 1968). The Amazonian clones were derived from the selection and crossings carried out in Brazil by the Ford Motor Company and the Instituto Agronomico do Norte (IAN), which is currently the Instituto de Pesquisa Agropecuária do Norte. The IAC genotypes resulted from controlled crossings and open pollinations performed by IAC.

A total of 30 EST-SSRs (Table 2) were selected from Feng et al. (2009). These markers were derived from a cDNA library developed to analyze gene expression in laticifers by Chow et al. (2007). Amplifications were performed in a final volume of $25 \mu \mathrm{L}$ containing $50 \mathrm{ng}$ DNA, $1 \mathrm{X}$ buffer, $0.2 \mu \mathrm{mol} \mathrm{L} \mathrm{L}^{-1}$ of each forward and reverse primer, $100 \mu \mathrm{mol} \mathrm{L}^{-1}$ of each dNTP, $2.0 \mathrm{mmol} \mathrm{L}^{-1} \mathrm{MgCl}_{2}, 10$ mmol L-1 Tris- $\mathrm{HCl}$ ( $\mathrm{pH} \mathrm{8.0)}$ ), $50 \mathrm{mmol} \mathrm{L}^{-1} \mathrm{KCl}$, and $0.5 \mathrm{U}$ Taq DNA polymerase. The following conditions were used for amplification: $1 \mathrm{~min}$ at $94^{\circ} \mathrm{C}$, then 30 cycles of $1 \mathrm{~min}$ at $94^{\circ} \mathrm{C}, 1 \mathrm{~min}$ at the specific annealing temperature for each SSR, and $1 \mathrm{~min}$ at $72^{\circ} \mathrm{C}$, with a final extension of $5 \mathrm{~min}$ at $72^{\circ} \mathrm{C}$. The PCR products were separated with $6 \%$ silver-stained polyacrylamide gel electrophoresis. Molecular size of the DNA fragments was estimated by comparison with standard 10-bp DNA ladder (Invitrogen, São Paulo, SP, Brazil). A binary matrix was constructed from the gel readings, in which the individuals were genotypically 
Table 1. Rubber tree selected clones and their respective genealogy.

\begin{tabular}{|c|c|c|}
\hline Clone number & Clone & Genealogy $\mathrm{y}^{(1)}$ \\
\hline 1 & Fx 2261 & F 1619 x AVROS 183 \\
\hline 2 & IAC 501 & RRIM 526 (Pil B 58 x Pil D 65) ill. \\
\hline 3 & IAC 502 & IAC 41 [RRIM 608 (AVROS 33 x Tjir 1) x AVROS 1279 (AVROS 256 x AVROS 374)] ill. \\
\hline 4 & IAC 503 & Fx $3899\left(\right.$ F $4542^{(2)}$ x AVROS 363) ill. \\
\hline 5 & IAC 505 & IAN 873 (PB 86 x FA 1717) ill. \\
\hline 6 & IAC 506 & AVROS 1513 ill. \\
\hline 7 & IAC 507 & IAC 90 [RRIM 507 (Pil B 94 x Pil A 44) x Fx 25 (F 351 x AVROS 49)] ill. \\
\hline 8 & IAC 508 & RRIM 512 (Pil B 84 x Pil A 44) ill. \\
\hline 9 & IAC 510 & IAC 23 ill. \\
\hline 10 & IAC 511 & IAC 15 [RRIM 504 (Pil A 44 x Lun N)] ill. \\
\hline 11 & IAC 512 & Fx 25 (F 351 x AVROS 49) ill. \\
\hline 12 & IAC 514 & FDR 1057 (Har 8 x IAN 873) ill. \\
\hline 13 & IAN 6323 & Tjir 1 x Fx 3810 (F 4542 x AVROS 363) \\
\hline 14 & IAN 873 & PB $86 \times$ FA 1717 \\
\hline 15 & IRCA 111 & PB 5/51 (PB 56 x PB 24) x RRIM 600 (Tjir 1 x PB 86) \\
\hline 16 & IRCA 18 & PB 5/51 (PB 56 x PB 24) x RRIM 605 (Tjir 1 x PB 49) \\
\hline 17 & PB 217 & PB $5 / 51($ PB 56 x PB 24) x PB 6/9 \\
\hline 18 & PC 119 & GT 1 x RRIM 703 [RRIM 600 (Tjir 1 x PB 86) x RRIM 500 (Pil B 84 x Pil A 44)] \\
\hline 19 & PC 140 & PB 5/51 (PB 56 x PB 24) x RRIM 703 [RRIM 600 (Tjir 1 x PB 86) x RRIM 500 (Pil B 84 x Pil A 44)] \\
\hline 20 & PC 96 & PB 5/51 (PB 56 x PB 24) x RRIM $600($ Tjir 1 x PB 86) \\
\hline 21 & PM 10 & PB IG Seedling \\
\hline 22 & RRIM 725 & Fx 25 (F 351 x AVROS 49) ill. \\
\hline 23 & RRIM 728 & GT 1 x RRIM 623 (PB 49 x Pil B 84) \\
\hline 24 & RRIM 802 & RRIM 501 (Pil A 44 x Lun N) x RRIM 71 \\
\hline 25 & Fx 4098 & PB $86 \times$ FB 110 \\
\hline 26 & IAC 325 & Tjir 16 x Fx 25 (F 351 x AVROS 49) \\
\hline 27 & PB 252 & PB 86 x PB 32/36 (PB 49 x PB 186) \\
\hline 28 & PB 260 & PB 5/51 (PB 56 x PB 24) x PB 49 \\
\hline 29 & PB 330 & PB 5/51 (PB 56 x PB 24) x PB 32/36 (PB 49 x PB 186) \\
\hline 30 & RRIM 710 & RRIM 605 (Tjir 1 x PB 49) x RRIM 71 \\
\hline 31 & RRIM 713 & RRIM 605 (Tjir 1 x PB 49) x RRIM 71 \\
\hline 32 & RRIM 714 & RRIM $605($ Tjir 1 x PB 49) x PB 49 \\
\hline 33 & RRIM 729 & RRIM 623 (PB 49 x Pil B 84) x Fx 25 (F 351 x AVROS 49) \\
\hline 34 & RRIM 801 & RRIM 628 [Tjir 1 x RRIM 527 (Pil B 50 x Pil B 84)] \\
\hline 35 & RRIM 806 & RRIM 600 (Tjir 1 x PB 86) x RRIM 623 (PB 49 x Pil B 84) \\
\hline 36 & RRIM 901 & PB 5/51 (PB 56 x PB 24) x RRIM 600 (Tjir 1 x PB 86) \\
\hline 37 & RRIM 908 & PB 5/51 (PB 56 x PB 24) x RRIM 623 (PB 49 x Pil B 84) \\
\hline 38 & RRIM 911 & PB 5/51 (PB 56 x PB 24) x RRIM 623 (PB 49 x Pil B 84) \\
\hline 39 & RRIM 915 & RRIM 605 (Tjir 1 x PB 49) x PB 5/51 (PB 56 x PB 24) \\
\hline 40 & RRIM 919 & RRIM $605($ Tjir 1 x PB 49) x PB 5/51 (PB 56 x PB 24) \\
\hline 41 & RRIM 938 & PB 5/51 (PB 56 x PB 24) x RRIM 703 [RRIM 600 (Tjir 1 x PB 86) x RRIM 500 (Pil B 84 x Pil A 44)] \\
\hline 42 & IAC 513 & PB 86 ill. \\
\hline 43 & IAC 504 & RRIM 600 (Tjir 1 x PB 86) ill. \\
\hline 44 & PB 235 true & PB 5/51 (PB 56 x PB 24) x PB S/78 (PB 49 x PB 25) \\
\hline 45 & PB 235 false & \\
\hline 46 & H. guianensis & Primary clone \\
\hline 47 & H. benthamiana & Primary clone \\
\hline 48 & H. rigidifolia & Primary clone \\
\hline 49 & H. nitida & Primary clone \\
\hline 50 & H. carmagoana & Primary clone \\
\hline 51 & H. pauciflora & Primary clone \\
\hline
\end{tabular}

(1)ill., illegitimate (clone of open pollinated plant). Malaysian clones: PC, promotion clone; PB, Prang Besar; RRIM, Rubber Research Institute of Malaysia; Pil, Pilmoor; Lun, Lunderston; PBIG, Prang Besar Isolated Garden; Tjir, Tjirandji; GT, Gondang Tapen. Amazonian Clones: F, Ford; FA, Ford Acre; FB, Ford Belém; Fx, Ford crossing; IAN, Instituto Agronômico do Norte. African clones: Har, Harbel; IRCA, Institut dés Recherches sur le Caoutchouc. Brazilian clones: IAC, Instituto Agronômico de Campinas. ${ }^{(2)}$ Hevea benthamiana clone. 
characterized for presence (1) and absence (0) of bands. The percentage of polymorphism obtained with each primer was calculated from this matrix.

Genetic distances (GDs) were calculated from the EST-SSR data for all possible inbred pairs using modified Roger's genetic distance (MRD) (Goodman \& Stuber, 1983), version 1.3 (Miller, 1997). Cluster analyses were performed using the unweighted pair-group method with arithmetic averages (UPGMA).

Polymorphism information content (PIC) values were calculated using the formula,

$$
\mathrm{PIC}=\sum_{\mathrm{i}=1}^{\mathrm{n}} \mathrm{f}_{\mathrm{i}}^{2}=1 \sum_{\mathrm{j}=\mathrm{i}+1}^{\mathrm{n}-\mathrm{i}} 2 \mathrm{fi}^{2} \times \mathrm{fj}^{2},
$$

in which: $\mathrm{n}$ is the number of alleles and $\mathrm{f}_{\mathrm{i}}$ and $\mathrm{f}_{\mathrm{j}}$ are the frequencies of the $i^{\text {th }}$ and $j^{\text {th }}$ alleles, respectively (Lynch
\& Walsh, 1998). Discrimination power (DP) values for the $\mathrm{k}^{\text {th }}$ primer were calculated using the formula,

$$
D p_{k}=1-\sum_{j=i}^{1} \times p_{j}\left[\left(\mathrm{~Np}_{j}-1\right) /(N-1)\right],
$$

in which: $\mathrm{N}$ is the number of individuals and $\mathrm{p}_{\mathrm{j}}$ is the frequency of the $\mathrm{j}^{\text {th }}$ pattern (Tessier et al., 1999). PIC was used to measure the information of a given marker locus for the pool of genotypes, whereas DP was used to measure the efficiency of SSRs in order to identify varieties by taking into account the probability of two randomly chosen individuals having different patterns. In addition, Wright $F$ statistics and molecular analysis of variance (AMOVA) were determined with Arlequin v. 3.11 (Excoffier et al., 2005).

Bayesianclustering was performed using the software Structure 2.2 (Pritchard et al., 2000). The number of

\begin{tabular}{|c|c|c|c|c|c|c|c|}
\hline Locus & Gene bank accession number & Repeat motif & Number of alleles & $\mathrm{Ta}\left({ }^{\circ} \mathrm{C}\right)^{(1)}$ & Size range $(\mathrm{bp})$ & $\mathrm{PIC}^{(2)}$ & $\mathrm{DP}^{(3)}$ \\
\hline HBE001 & EC609907.1 & $(\mathrm{CTT}) 13$ & 8 & 54.4 & $124-100$ & 0.72 & 0.53 \\
\hline HBE004 & EC609720.1 & $(\mathrm{GCA}) 8$ & 3 & 53.2 & $114-102$ & 0.29 & 0.31 \\
\hline HBE014 & EC609118.1 & (CTG)6 & 7 & 55.4 & $212-186$ & 0.54 & 0.24 \\
\hline HBE017 & EC608908.1 & $(\mathrm{ATG}) 6$ & 6 & 55.4 & $158-134$ & 0.75 & 0.90 \\
\hline HBE021 & EC608805.1 & (TA) 11 & 5 & 56.2 & $164-150$ & 0.43 & 0.07 \\
\hline HBE022 & EC608800.1 & (GCA)6 & 4 & 56.2 & $320-170$ & 0.60 & 0.17 \\
\hline HBE034 & EC608405.1 & $(\mathrm{TTC}) 6$ & 4 & 56.2 & $210-186$ & 0.60 & 0.25 \\
\hline HBE043 & EC608110.1 & $(\mathrm{CTT}) 8$ & 4 & 56.2 & $264-252$ & 0.64 & 0.38 \\
\hline HBE051 & EC607870.1 & $(\mathrm{ATC}) 6$ & 3 & 57 & $158-152$ & 0.51 & 0.33 \\
\hline HBE056 & EC607524.1 & (TC)6 & 3 & 57 & $158-152$ & 0.52 & 0.08 \\
\hline HBE063 & EC607362.1 & $(\mathrm{GA}) 16$ & 7 & 57 & $240-194$ & 0.78 & 0.66 \\
\hline HBE067 & EC607289.1 & $(\mathrm{GGC}) 7$ & 5 & 57 & $222-216$ & 0.66 & 0.35 \\
\hline HBE077 & EC606911.1 & $(\mathrm{TC}) 14$ & 7 & 53.4 & $320-230$ & 0.76 & 0.65 \\
\hline HBE090 & EC606350.1 & $(\mathrm{GAT}) 12$ & 3 & 57 & $370-360$ & 0.50 & 0.18 \\
\hline HBE103 & EC606060.1 & $(\mathrm{GA}) 6(\mathrm{CTG}) 7 \mathrm{c}(\mathrm{T}) 12$ & 7 & 57 & $330-198$ & 0.70 & 0.51 \\
\hline HBE 117 & EC605512.1 & $(\mathrm{CAC}) 6$ & 10 & 57 & $280-200$ & 0.86 & 0.79 \\
\hline HBE122 & EC605312.1 & (ATA)8 & 5 & 57 & $216-196$ & 0.74 & 0.80 \\
\hline HBE126 & EC605124.1 & $(\mathrm{AAG}) 10$ & 8 & 57 & $220-198$ & 0.75 & 0.59 \\
\hline HBE 140 & EC604443.1 & $(\mathrm{CAT}) 7$ & 3 & 57 & $144-140$ & 0.59 & 0.20 \\
\hline HBE146 & EC603602.1 & (TGC)6 & 3 & 57 & $138-132$ & 0.40 & 0.28 \\
\hline HBE164 & EC603146.1 & (AG)6 & 5 & 57 & $170-130$ & 0.26 & 0.23 \\
\hline HBE 167 & EC603048.1 & (GGTGAT)6 & 8 & 57 & $302-280$ & 0.83 & 0.71 \\
\hline HBE187 & EC601817.1 & $(\mathrm{CT}) 6$ & 4 & 55.4 & $150-144$ & 0.70 & 0.52 \\
\hline HBE189 & EC601635.1 & (TTC)8 & 3 & 57 & $112-108$ & 0.65 & 0.48 \\
\hline HBE 190 & EC601511.1 & $(\mathrm{CTT}) 11$ & 2 & Touchdown & $170-162$ & 0.39 & 0.19 \\
\hline HBE192 & EC601354.1 & $(\mathrm{GGA}) 9$ & 7 & Touchdown & $208-172$ & 0.74 & 0.25 \\
\hline HBE193 & EC601277.1 & $(\mathrm{TC}) 14$ & 4 & 57 & $158-152$ & 0.62 & 0.26 \\
\hline HBE196 & EC601217.1 & (AT)35 & 4 & 57 & $154-120$ & 0.57 & 0.41 \\
\hline HBE200 & EC600725.1 & (GA)6 & 4 & 57 & $186-154$ & 0.23 & 0.42 \\
\hline HBE206 & EC600478.1 & (TGC)6 & 3 & 57 & $168-158$ & 0.42 & 0.29 \\
\hline
\end{tabular}

Table 2. Data from the 30 EST-SSRs markers used to genotype the 51 rubber tree clones.

${ }^{(1)} \mathrm{Ta}$, annealing temperature. ${ }^{(2)} \mathrm{PIC}$, polymorphism information content. ${ }^{(3)} \mathrm{DP}$, discrimination power. 
clusters was defined from $K=2$ to $K=20$, and ten runs of each $\mathrm{K}$ were carried out using: the admixture model and correlated allele frequencies, a 200,000 burn-in period, and 500,000 MCMC. Ad hoc statistics were related to rate changes in the log probability of data according to the number of Ks proposed by Evanno et al. (2005), with $\Delta \mathrm{K}$ being used as a predictor of the ideal number of clusters.

\section{Results and Discussion}

All of the thirty EST-SSRs were polymorphic (Table 2) and produced a total of 149 polymorphic alleles. The number of alleles ranged from two to ten, with a mean of 4.96 alleles per marker. The highest number of alleles was observed for the microsatellites HBE001, HBE117, HBE126, and HBE167.

The highest value of PIC found for EST-SSRs was 0.86 (HBE117) and the lowest was 0.23 (HBE200), with a mean value of 0.59. Souza et al. (2009) assessed the genetic diversity of $H$. brasiliensis and six wild species of rubber tree using genomic SSR markers and reported a similar range for PIC values (0.13 to 0.88 ).

Cross-species amplification with the 30 EST-SSRs was successful for the six wild species evaluated in the present study. Saha et al. (2005) also observed that SSRs specifically developed for $H$. brasiliensis efficiently amplified $H$. benthamiana and $H$. spruceana . Other studies indicated that SSRs developed for H. brasiliensis were successfully transferable to Hevea wild species (Souza et al., 2009; Gouvêa et al., 2010; Le Guen et al., 2011).

The DP analyses (Table 2) showed values ranging from 0.07 (HBE017) to 0.90 (HBE021). According to the number of alleles, discrimination power, and polymorphic information content, the polymorphism estimated for the rubber tree with EST-SSRs indicated that these loci were capable of generating sufficient information to ensure their use to establish genetic relationships among closely related materials. These markers could also be useful for a wide range of genetic investigations, such as linkage map construction and association mapping studies.

Genotypes (Figure 1) showed high genetic variability, as genetic distances varied from 0.35 to 0.77 , and a high genetic structure was observed from the clustering pattern. Similar genetic distances $(0.26$ to 0.67$)$ were found by Gouvêa et al. (2010), who reported high genetic variability among rubber tree genotypes.
The 51 clones were separated into two major groups. The first group was composed mostly of IAC clones, developed within the IAC breeding program. Fewer Amazonian, Asian, and African clones were also included in this group. The second group consisted of Malaysian clones from the Rubber Research Institute of Malaysia (RRIM). This group showed a clear separation between wild Hevea species, in comparison to other $H$. brasiliensis genotypes. These samples have undergone several breeding cycles, as confirmed by the highest interspecific genetic distances observed. The smallest genetic distances were intraspecific, belonging to genotypes derived from the same breeding institution (Group 1: PB, Prang Besar; Group 2: PB and RRIM) (Figure 1). Moreover, IAC clones (Group 1) showed greater genetic distances than Malaysian clones (Group 2), indicating a greater genetic variability among Brazilian genotypes, which could be explained by the selection pressure present in each breeding program.

The overall observed heterozygosity (Ho) assessed for group 1 was 0.25883 , and the expected heterozigosity $(\mathrm{He})$ was 0.60264 ; for group 2, Ho was 0.27090 and $\mathrm{He}$ was 0.51366 . The pair-wise $\mathrm{F}_{\mathrm{ST}}$ (Weir \& Cockerham, 1984) was high (27.64\%), indicating great variability among the dendrogram groups $\left(\mathrm{F}_{\mathrm{ST}}\right)$. Furthermore, $72.36 \%$ of variation was contained within the populations $\left(\mathrm{F}_{\mathrm{IS}}\right)$.

The cophenetic correlation coefficient was high $(\mathrm{r}=0.70, \mathrm{p}<0.002)$, indicating that UPGMA clustering accurately represented the genetic distances among rubber tree clones. Gouvêa et al. (2010) observed a similar cophenetic value for the genomic SSR UPGMA clustering. Odong et al. (2011) found a relationship between the cophenetic correlation coefficient (CPCC) and subgroup differentiation $\left(\mathrm{F}_{\mathrm{ST}}\right)$, and that a high CPCC with UPGMA clustering is an indication of a reliable population structure in the data.

The EST-SSRs used in the present study were efficient in promoting the distinction of rubber tree accessions that have common male and female parents, as observed by the following clones: RRIM 710 and RRIM 713, whose parents were RRIM 605 and RRIM 71; RRIM 908 and RRIM 911, derived from the PB 551 and RRIM 623 intersection; and RRIM 915 and RRIM 919, whose parents were RRIM 605 and PB 5/51 (Figure 1).

The clones PB 235 (false) and PB 235 (true) were differentiated (Figure 1) by the EST-SSRs, proving that these markers can be extremely useful for conducting effective fingerprinting analysis. In fact, fingerprinting 
was applied to verify the identity of parental clones during micropropagation and to certify the purity of $F_{1}$ hybrids. The use of molecular markers to perform fingerprinting analysis was reported in other studies (Caruso et al., 2008; Van Treuren et al., 2010), with the same efficiency, to separate phenotypically similar genotypes, such as the two PB 235 clones used in the present study.

The EST-SSRs, despite being developed from $H$. brasiliensis, were able to amplify other species of Hevea. This transferability is very important in the sense that it enables the use of microsatellite analysis in intra- and interspecific genetic diversity and gene flow evaluation, as well as phylogenetic relationships between cultivated clones of $H$. brasiliensis and of other species of wild Hevea. Souza et al. (2009) used genomic and microsatellite markers and also observed transferability of loci with wild species. Mantello et al. (2012) found a percentage of transferability from 82 to $87 \%$.
According to $\mathrm{Yu}$ et al. (2011), there are homogeneous microsatellite sequences within species, between species, and across genes. All evidence indicates that, with large genetic distances, the ability to amplify microsatellite loci with the same primer pairs decreases. These authors found a good discriminatory power for genomic microsatellites used to investigate genetic diversity and that these loci were similar to the EST-SSRs reported by Feng et al. (2009). Indeed, EST-SSRs were efficiently used to access the genetic diversity of $H$. brasiliensis, being capable of dividing the genotypes into two major and clearly structured groups.

A total of eight groups were identified by $\Delta \mathrm{K}$ as being the ideal number of groups, according to Evanno et al. (2005). Feng's SSRs were used to establish a correspondence between the dendrogram and Structure clustering (Figures 1 and 2). It was observed that group 1 of the dendrogram corresponded entirely to Structure groups I, II, IV, and VI. Group 2 of the dendrogram

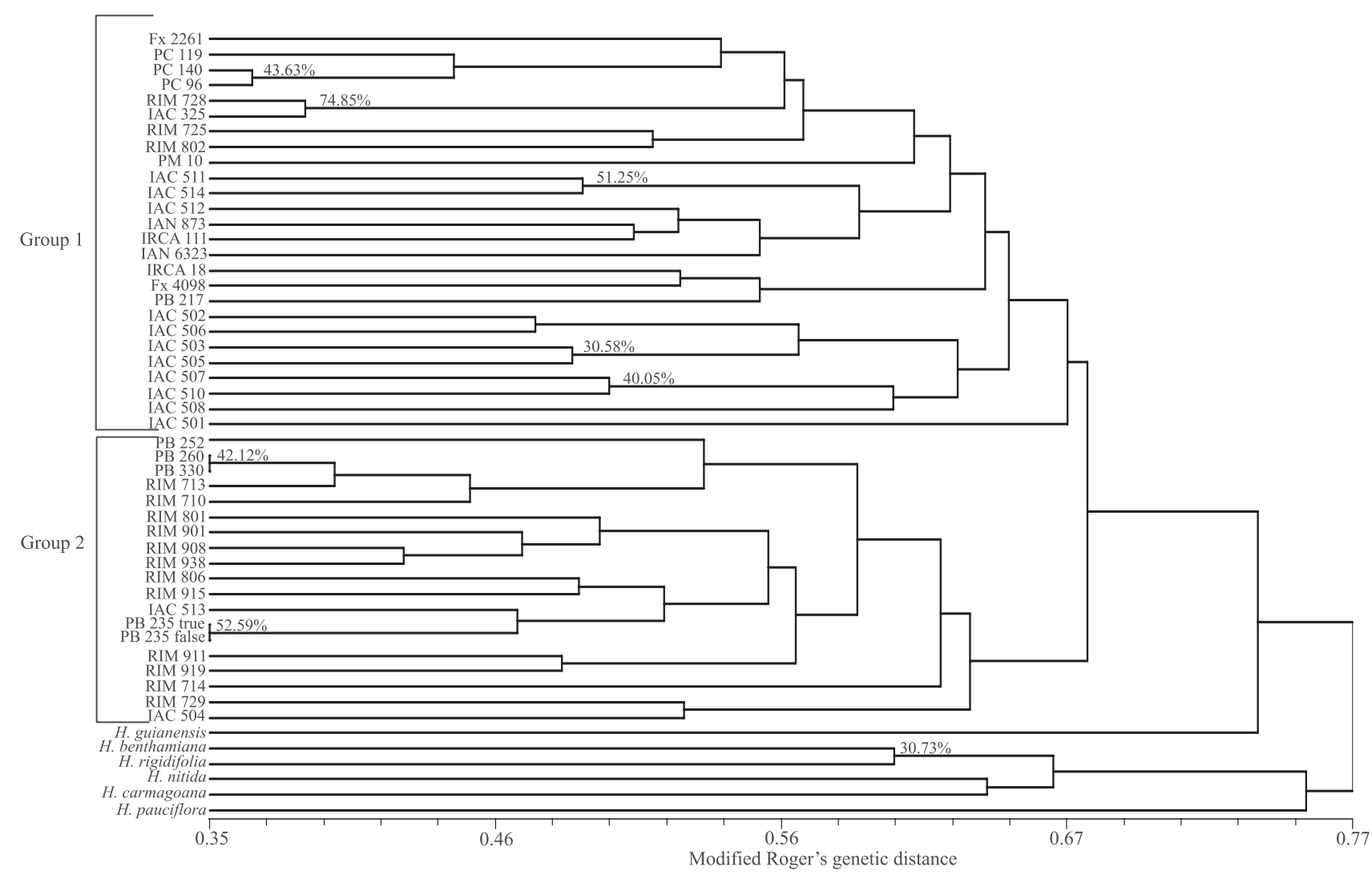

Figure 1. UPGMA cluster analysis of modified Roger's genetic distances based on data from 30 EST-SSRs, used in the evaluation of the 51 rubber tree clones. Bootstrap node supports were represented in percentages. 


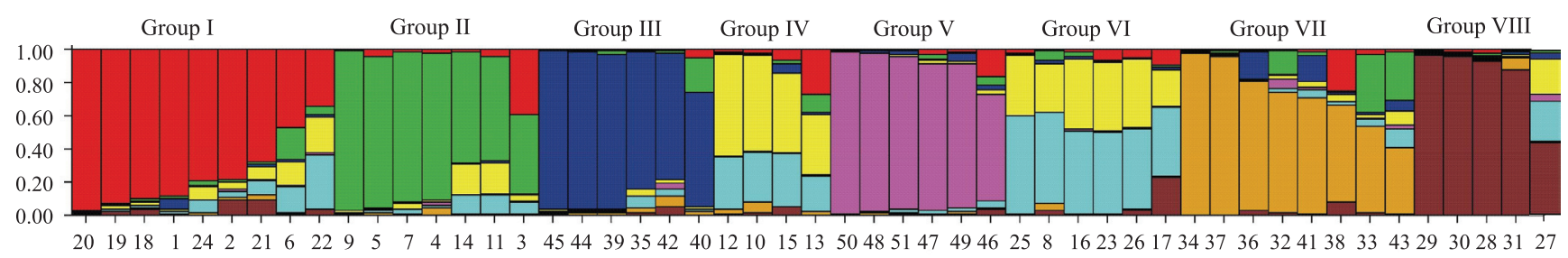

Figure 2. Distribution of the 51 rubber tree clones in groups according to Structure analysis $(\mathrm{k}=8)$, based on the 30 ESTSSRs used in the evaluation of the 51 rubber tree genotypes. The clones were represented by vertical bars and each color is associated to a different group. Genotype identification number is shown on Table 1.

corresponded to Structure groups III and VII, whereas group 3 corresponded entirely to group VI of the Structure clustering. Therefore, Structure analysis was also efficient to access the genetic organization of Hevea species, although it tended to generate a deeper subgroup differentiation. The consistency in genotype clusters indicated a nonrandom distribution of alleles and their frequencies. A parallel could be established between both analyses, but UPGMA clustering was clearer. According to Odong et al. (2011), traditional cluster analysis, such as UPGMA, can provide an easier and more effective way of determining structure in germplasm collections, using molecular marker data, in comparison to Bayesian methods.

Microsatellites derived from genic sequences (EST-SSR) have additional advantages because they can be developed from regions of the genome associated with a trait of interest and could be part of the gene controlling the character (Thiel et al., 2003). Another advantage is the fact that the gene regions are more conserved, when compared to anonymous ones. Therefore, these functional markers are likely to be more easily transferred to related species (Varshney et al., 2005).

\section{Conclusions}

1. The EST-SSRs are efficient to evaluate genetic diversity among rubber tree accessions.

2. EST-SSRs can be used to translate the genetic differences among cultivars and fingerprint closely related materials.

3. The EST-SSRs developed from Hevea brasiliensis show transferability and are able to amplify other species of Hevea.

4. The accessions from Instituto Agronômico (IAC) show high genetic diversity.

\section{Acknowledgments}

To Fundação de Amparo à Pesquisa do Estado de São Paulo and to Conselho Nacional de Desenvolvimento Científico e Tecnológico, for scholarships granted.

\section{References}

BRONDANI, R.P.V.; BRONDANI, C.; TARCHINI, R.; GRATTAPAGLIA, D. Development, characterization and mapping of microsatellite markers in Eucalyptus grandis and E. uruphylla. Theoretical and Applied Genetics, v.97, p.816-827, 1998.

CARUSO, M.; FEDERICI, C.T.; ROOSE, M.L. EST-SSR markers for asparagus genetic diversity evaluation and cultivar identification. Molecular Breeding, v.21, p.195-204, 2008.

CHOW, K.-S.; WAN, K.-L.; ISA, M.N.M.; BAHARI, A.; TAN, S.H.; HARIKRISHNA, K.; YEANG, H.Y. Insights into rubber biosynthesis from transcriptome analysis of Hevea brasiliensis latex. Journal of Experimental Botany, v.58, p.2429-2440, 2007.

EVANNO, G.; REGNAUT, S.; GOUDET, J. Detecting the number of clusters of individuals using the software STRUCTURE: a simulation study. Molecular Ecology, v.14, p.2611-2620, 2005.

EXCOFFIER, L.; LAVAL, G.; SCHNEIDER, S. Arlequin (version 3.0): an integrated software package for population genetics data analysis. Evolutionary Bioinformatics, v.1, p.47-50, 2005.

FENG, S.P.; LI, W.G.; HUANG, H.S.; WANG, J.Y.; WU, Y.T. Development, characterization and cross-species/genera transferability of EST-SSR markers for rubber tree (Hevea brasiliensis). Molecular Breeding, v.23, p.85-97, 2009.

GONÇALVES, O.S.; MARQUES, J.R.B. Melhoramento genético da seringueira: passado, presente e futuro. In: ALVARENGA, A. de P.; CARMO, C.A.F. de S. do (Coord.). Seringueira. Viçosa: EPAMIG, 2008. p.399-498.

GOODMAN, M.M.; STUBER, C.W. Races of maize. VI. Isozyme variation among races of maize in Bolivia. Maydica, v.28, p.169-187, 1983.

GOUVÊA,L.R.L.; RUBIANO,L.B.; CHIORATTO,A.F.;ZUCCHI, M.I.; GONÇALVES, P. de S. Genetic divergence of rubber tree estimated by multivariate techniques and microsatellite markers. Genetics and Molecular Biology, v.33, p.308-318, 2010. 
HOISINGTON, D.; KHAIRALLAH, M.; GONZALEZ DE LEÓN, D. Laboratory protocols: CIMMYT applied molecular genetics laboratory. $2^{\text {nd }}$ ed. Mexico: CIMMYT, 1994. 102p.

INTERNATIONAL RUBBER STUDY GROUP. Statistical summary of world rubber situation. Available at: $<$ http://www. rubberstudy.com>. Accessed on: 23 Aug. 2011.

LE GUEN, V.; DOARÉ, F.; WEBER, C.; SEGUIN, M. Genetic structure of Amazonian populations of Hevea brasiliensis is shaped by hydrographical network and isolation by distance. Tree Genetics and Genomes, v.5, p.673-683, 2009.

LE GUEN, V.; GAY, C.; XIONG, T.C.; SOUZA, L.M.; RODIER-GOUD, M.; SEGUIN, M. Development and characterization of 296 new polymorphic microsatellite markers for rubber tree (Hevea brasiliensis). Plant Breeding, v.130, p.294-296, 2011.

LYNCH, M.; WALSH, J.B. Genetics and analysis of quantitative traits. Sunderland: Sinauer, 1998. 980p.

MANTELLO, C.C.; SUZUKI, F.I.; SOUZA, L.M.; GONÇALVES, P. de S.; SOUZA, A.P. Microsatellite marker development for the rubber tree (Hevea brasiliensis): characterization and cross-amplification in wild Hevea species. BMC Research Notes, v.5, 2012. Doi:10.1186/1756-0500-5-329.

MILLER, M. Tools for population genetic analyses (TFPGA). Version 1.3. Flagstaff: Northern Arizona University, 1997. 33p.

ODONG, T.L.; HEERWAARDEN, J. van; JANSEN, J.; HINTUM, T.J.L. van; EEUWIJK, F.A. van. Determination of genetic structure of germplasm collections: are traditional hierarchical clustering methods appropriate for molecular marker data? Theoretical and Applied Genetics, v.123, p.195-205, 2011.

PRITCHARD, J.K.; STEPHENS, M.; DONNELLY, P. Inference of population structure using multilocus genotype data. Genetics, v.155, p.945-959, 2000.

PRIYADARSHAN, P.M.; GONÇALVES, P. de S. Hevea gene pool for breeding. Genetic Resources and Crop Evolution, v.50, p.101-114, 2003.

ROY, C.B.; NAZEER, M.A.; SAHA, T. Identification of simple sequence repeats in rubber (Hevea brasiliensis). Current Science, v.87, p.807-811, 2004.

SAHA, T.; ROY, C.B.; NAZEER, M.A. Microsatellite variability and its use in the characterization of cultivated clones of Hevea brasiliensis. Plant Breeding, v.124, p.86-92, 2005.
SAHA, T.; ROY, C.B.; RAVINDRAN, M.; BINI, K.; NAZEER, M.A. Allelic diversity revealed through SSR polymorphisms at the locus encoding HMG-CoAreductase in rubber (Hevea brasiliensis). Silvae Genetica, v.56, p.58-65, 2007.

SOUZA, L.M.; MANTELLO, C.C.; SANTOS, M.O.; GONÇALVES, P. de S.; SOUZA, A.P. Microsatellites from rubber tree (Hevea brasiliensis) for genetic diversity analysis and cross-amplification in six Hevea wild species. Conservation Genetics Resources, v.1, p.75-79, 2009.

TESSIER, C.; DAVID, J.; THIS, P.; BOURSIQUOT, J.M.; CHARRIER, A. Optimization of the choice of molecular markers for varietal identification in Vitis vinifera L. Theoretical and Applied Genetics, v.98, p.171-177, 1999.

THIEL, T.; MICHALEK, W.; VARSHNEY, R.K.; GRANER, A. Exploiting EST databases for the development and characterization of gene-derived SSR-markers in barley (Hordeum vulgare L.). Theoretical and Applied Genetics, v.106, p.411-422, 2003.

VAN TREUREN, R.; KEMP, H.; ERNSTING, G.; JONGEJANS, B.; HOUTMAN, H.; VISSER, L. Microsatellite genotyping of apple (Malus x domestica Borkh.) genetic resources in the Netherlands: application in collection management and variety identification. Genetic Resources and Crop Evolution, v.57, p.853-865, 2010.

VARSHNEY, R.K.; GRANER, A.; SORRELLS, M.E. Genic microsatellite markers in plants: features and applications. Trends in Biotechnology, v.23, p.48-55, 2005.

VARSHNEY, R.K.; SIGMUND, R.; BORNER, A.; KORZUN, V.; STEIN, N.; SORRELLS, M.E.; LANGRIDGE, P.; GRANER, A. Interspecific transferability and comparative mapping of barley EST-SSR markers in wheat, rye and rice. Plant Science, v.168, p.195-202, 2005.

WEIR, B.S.; COCKERHAM, C.C. Estimating F-statistics for the analysis of population structure. Evolution, v.38, p.1358-1370, 1984.

WYCHERLEY, P.R. Introduction of Hevea to the Orient. The Planter, v.44, p.127-137, 1968.

YU, F.; WANG, B.-H.; FENG, S.-P.; WANG, J.-Y.; LI, W.-G.; WU, Y.-T. Development, characterization, and cross-species/genera transferability of SSR markers for rubber tree (Hevea brasiliensis). Plant Cell Reports, v.30, p.335-344, 2011.

Received on April 4, 2012 and accepted on July 16, 2012 